\title{
Integrating Chinese Culture into College English Teaching Against the Background of "the Belt and Road Initiatives"
}

\author{
Qingqing Fang \\ Foreign Language Department \\ Wuchang Shouyi University \\ Wuhan, Hubei, China \\ 455676391@qq.com
}

\begin{abstract}
Against the background of "the Belt and Road Initiatives", college English teaching need to cultivate students' ability of cross-cultural communication, especially the ability to transmit Chinese culture to foreign countries. However, nowadays most of the college English teaching focuses more on teaching students the knowle dge about western culture, ignoring teaching how to express Chinese culture in English. This article aims to emphasize on the input of Chinese culture in college English teaching. By using the method of literature and theoretical analysis, the paper analyses the phenomenon of "aphasia of Chinese culture" and its causes. It also explores the strategies of integrating Chinese culture into college English teaching in the aspects of teaching materials, teaching methods, systematic courses of Chinese culture and tests.
\end{abstract}

Keywords-the Belt and Road Initiatives; Chinese culture; aphasia of Chinese culture ; college English teaching

\section{INTRODUCTION}

In 2013, Chinese president Xi put forward the "the Belt and Road Initiatives”, which symbolize the strategic transformation of the Chinese reform and opening up. Against this background, countries along the Belt and the Road have more cultural communications than before. Cultural exchange is the important means of public diplomacy among countries in the world. It is also a strategic measure for us to spread the voice of china and transmit Chinese culture to the world [1].

As part of the various kinds of cultures in the world, Chinese culture needs to be transmitted to all parts of the world in a language that's accepted internationally, that is the English language. Therefore, teachers need to teach students to learn the knowledge about Chinese culture and how to express Chinese culture in English fluently. Those talents should have the global view, Chinese sentiment, and be good at grasping opportunities to take the initiative in the global competition.

It is commonly known that college English is the public basic course in college education system. It undertakes the important task of cultivating students overall language using abilities. One of the important requirements of the course is to make students have the cross-cultural communication abilities.

Over the decades, there are many reforms in college English teaching. Students' abilities of cross-cultural communication and culture literacy have been improved a lot. However, when cultivating students cross-cultural communication abilities, people pay more attention to the input the knowledge of western cultures, ignoring the learning of Chinese culture and its English expressions. As a result, students usually don't know how to express Chinese culture in English. For example, students may know clearly about the typical western wedding dress, but they don't know how to introduce Chinese traditional costumes such as Cheongsam. They can speak in English fluently about the coffee and the Starbucks, but they don't know how to introduce Chinese tea and tea culture. So they lack the ability of expressing Chinese culture in English. So it lead to the phenomenon of "aphasia of Chinese culture"[2].

\section{CAuses of the “APHASiA OF Chinese CUlture” PHENOMENON}

\section{A. “Aphasia of Chinese Culture” Phenomenon}

Many scholars have done researches on "aphasia of Chinese culture" phenomenon. Statistics show that only 25.39\% of students know how to express Chinese food in correct English. 28.57\% of students know how to introduce traditional Chinese festivals such spring festival, Mid-autumn festival and Dragon-boat Festival in English. 30.95\% of students know how to introduce the Chinese historical sites in English. That means the majority of Chinese college students don't know how to express Chinese culture in accurate English [3].

That's to say, when conducting cross-cultural communications with foreigners, students are usually good at explaining the foreign cultures, but they don't know how to introduce Chinese culture in English. Therefore this leads to the non-equivalence of the two cultures and the "aphasia of Chinese culture”.

In a word, there are few English language courses about Chinese culture in the present college English teaching, and few researches on related teaching methods. Students seldom have the chance to expose to the Chinese culture in the English class. This leads to students' incapability of conveying content of Chinese culture in English. What's more, the lack of 
teaching Chinese culture in colleges makes students know very little about the content of Chinese culture. Hence the "aphasia of Chinese culture" phenomenon indicates that it is an imperative task for us to integrated Chinese culture into college English teaching.

\section{B. Limitation of Cultural Cognition}

Culture contains a wide range of contents, including literature knowledge, art, law, folklore, morality, beliefs, and social habits etc [4]. Culture has the social attributes because we often see the culture of others through our own cultural perspective. We often judge someone from the social culture, while each individual represents diverse manifestations in culture. So it often leads to the misjudging because people have limited cognition about culture. According to the linguist Litterwood, when we adopt a new language mode, to some extent we give up some of the original cultural identity and accept another culture's way of understanding the world[5]. Namely, when we learn and speak English, we accept the way of seeing the world in English cultures, at the same time we give up some of the Chinese culture identity to some extent.

\section{Lack of Chinese Culture in Textbooks}

Teaching materials are the main tools for conveying cultural knowledge to students. In college English teaching, the learning of knowledge in the class and the after-class exercises mostly rely on teaching materials. Therefore, to some degree, the teaching materials determine what the students can learn in class. However, the content of current college English teaching focuses more on foreign language and literature. Most of the teaching materials in the textbooks are some English proses, novels and poems. There is a lack of relevant contents of Chinese culture.

For example, in the Reading and Writing course textbook "New Horizon College English", most of the reading articles reflect the Western culture and values. The content involving Chinese culture is extremely rare. There is a serious loss of balance in the proportion between Chinese and Western cultures. In the listening and speaking course textbook, "New Century College English Learning to Speak", all the listening materials and videos are about foreign countries.

The long-term use of such teaching materials in college English teaching will result in the lack of input of Chinese culture. Therefore students cannot have effective output of content related to Chinese culture and cannot achieve the real goal of improving students' cross-cultural communication abilities, let alone the abilities to transmit Chinese culture to the other parts of the world.

\section{Lack of Contrast Between Western and Chinese Culture}

Contrastive analysis plays an important role in language learning. When a person is learning a new language, his thinking will be influenced by both the mother tongue and the target language. The contrastive analysis of the two languages helps students to understand clearly about the differences and also the connections between two cultures. And students can have a deeper understanding of the languages and cultures they are learning [6].
So, we need to strengthen the integration of Chinese culture into college English teaching in order to cultivate the students' ability to express Chinese culture in English and also to improve their comparative analysis skills of two cultures. Then they can also set up their own rational judgments and values.

\section{StRATEGIES OF INTEGRATING CHINESE CULTURE INTO COLLEGE ENGLISH TEACHING}

\section{A. Adding the Content About Chinese Culture in English Teaching Materials}

The lack of content about Chinese culture in current teaching materials is a big problem. So it is very important to add the content about Chinese cultural in English in the teaching materials in college English. Then the revision of the existing English teaching materials is necessary.

First, it is necessary to increase the content of Chinese culture in various teaching textbooks and select some content that can reflect and represent traditional Chinese culture and characteristics. Add some relevant exercises to consolidate students' learning about expressing Chinese culture in English.

Second, teachers can recommend some typical English reading books about Chinese culture to students as the comprehensive reading, which can increase the input of Chinese culture.

Third, college English teachers can do some survey about the topics of Chinese culture that students are interested in and then select the interesting topics that students like, write suitable English learning materials about Chinese culture for students to meet their needs and English level. These can arouse students' interests of English learning, stimulate them to refer to more information about Chinese culture, and thus improve the ability to use English to express Chinese culture.

\section{B. Conducting Effective Teaching Methods}

The diversification of teaching methods plays an important role in the teaching results. So When teaching cultures, teachers can use various methods in teaching activities such as cultural penetration, analysis of literature, and comparative analysis of different cultures. And theme teaching methods, situational teaching methods, and translating teaching methods are relatively effective methods for the study of Chinese and Western cultures.

Take the translating teaching method as an example. The process of translation is to decode one language and then recode another language. In the translating exercises, adding sentences and articles about the content of Chinese culture can enable students to profoundly perceive the differences between the Chinese and Western ways of thinking and then understand the essence of Chinese culture.

In addition, when teaching different themes about Chinese culture, teachers should ensure a certain amount of language input through different forms such as the video, audio, reading texts etc. and then teachers should arrange different activities for students to practice the language output , such as group situational conversations, written reports, translation exercises, 
etc. By participating in various activities, students can improve the ability to use English to express Chinese culture.

What's more, there are so many smart ways that are used in English teaching nowadays, so the teaching of Chinese culture in English should also make use of some mobile phone apps to conduct class activities as part of the smart education.

\section{Setting up Systematic Courses of Chinese Culture}

Setting up culture courses systematically in college English education should meet the needs of the social background of "the Belt and the Road Initiatives". It should aim to cultivate students' two-way cross-cultural communication ability and the cultural innovation ability. In order to achieve the goal, the position of Chinese culture courses in college English curriculum structure should be taken into consideration. So, when setting up culture courses of college English, besides the western culture courses, we should also strengthen the construction of Chinese culture courses. In the first year, we can set up some culture courses in Chinese language, which can let students know more knowledge about our nation's culture. Those courses can be made as the public optional courses. In the second year, we can set up the courses of expressing Chinese culture in English version. Students can learn how to express Chinese culture fluently in accurate English, and tell Chinese stories well. In the third year, we can set up cross-cultural comparative courses. Through comparing and contrasting, students get to know deeply about the essence of Chinese culture and improve their critical thinking abilities. We can also set up some English optional courses which classify Chinese culture in different categories, such as philosophy, religion, literature, traditional customs and etiquette, food culture etc.[7].

\section{Conducting Tests About Expressing Chinese Culture in English}

Currently, as the form of assessments, tests are still one of the main means to examine students language level and then to promote learning and teaching in colleges. So in order to improve students' ability to express Chinese culture in English, we need to reform and improve our assessing system.

Before October 2013, there were few tests items that test the ability to express Chinese culture in English in the various English exams in the whole country, including the CET-4. Fortunately, this situation has been changed in recent years. In the 2013 College English Test Band4 and Band6, there were translating paragraphs about China's history, culture, economy, and social development. Such changes not only require the students to achieve certain level of language skill, but also emphasize on students' understanding of Chinese culture, especially students' ability to use English to express Chinese culture. So in order to fully exert the effect of tests, we should add the corresponding tests items about using English to express Chinese culture when testing English listening, speaking, reading, writing and translation. The purpose is to promote students' learning of the Chinese culture content, thus improve their English language skill and ability to express Chinese culture.

\section{CONCLUSION}

College English teaching should promote students language skills, overall ability of language using, and the improvement of culture literacy. And integrating Chinese culture into college English teaching can also improve students' culture literacy, students' cross-cultural communication abilities and critical thinking abilities. In addition, strengthening the teaching of Chinese culture in college English teaching can help students establish a correct view of culture, improve the ability of cultural identification and increase cultural selfconfidence. It helps to cultivate all-round talents who can adapt to the development of times and society.

Against the background of the "the Belt and Road Initiatives", Chinese culture needs to step forward to the world. College English teaching must emphasize on cultivating the students' abilities to spread Chinese culture to the outside world and the abilities tell Chinese stories well. Therefore, it is crucial to integrate Chinese culture into college English teaching in order to improve students' ability of using English to convey Chinese culture, thus promote the ability of the cross-cultural communication.

\section{ACKNOWLEDGMENT}

This paper is supported by one teaching research project in Wuchang Shouyi University approved in 2017(Project No.2017Y08). The name of the project is "A Study on the Effect of Integrating Chinese Culture into Oral English teaching on College Student's English Speaking Ability”.

\section{REFERENCES}

[1] Yan xin Wang, The Belt and Road Initiatives leading to the globalization of higher education, Guangming Daily, 2015(5).

[2] Cong Cong, “Aphasia of Chinese culture”: shortcomings of English teaching in China, Guangming Daily, 2000(10).

[3] Weiming Zhang, Hongmei Zhu, Chinese culture in college English teaching, Tsinghua University Education Research. 2002(2). No. S1 2002.

[4] Kramasch, C., Language and culture. Oxford; New York: Oxford University Press, 1998.

[5] Baohong Gao, The Cognitive view of culture in communicative fore ign language teaching, Foreign language and Foreign language teaching, 2003(8).

[6] Baijing Han, Fen xue, From conflict to coordination: the dynamic construction of bilingual culture identity of Chinese English learners, Journal of Gansu Lianhe University, 2012(6).

[7] Min Guo, The necessity and ways of integrating Chinese culture into college English teaching, Journal of Inner Mongolia Normal university(educational science), 2014(11), pp.137. 